\title{
Observaciones sobre el desarrollo de las facultades anímicas en los niños ${ }^{\star}$
}

\section{DIETRICH TIEDEMANN}

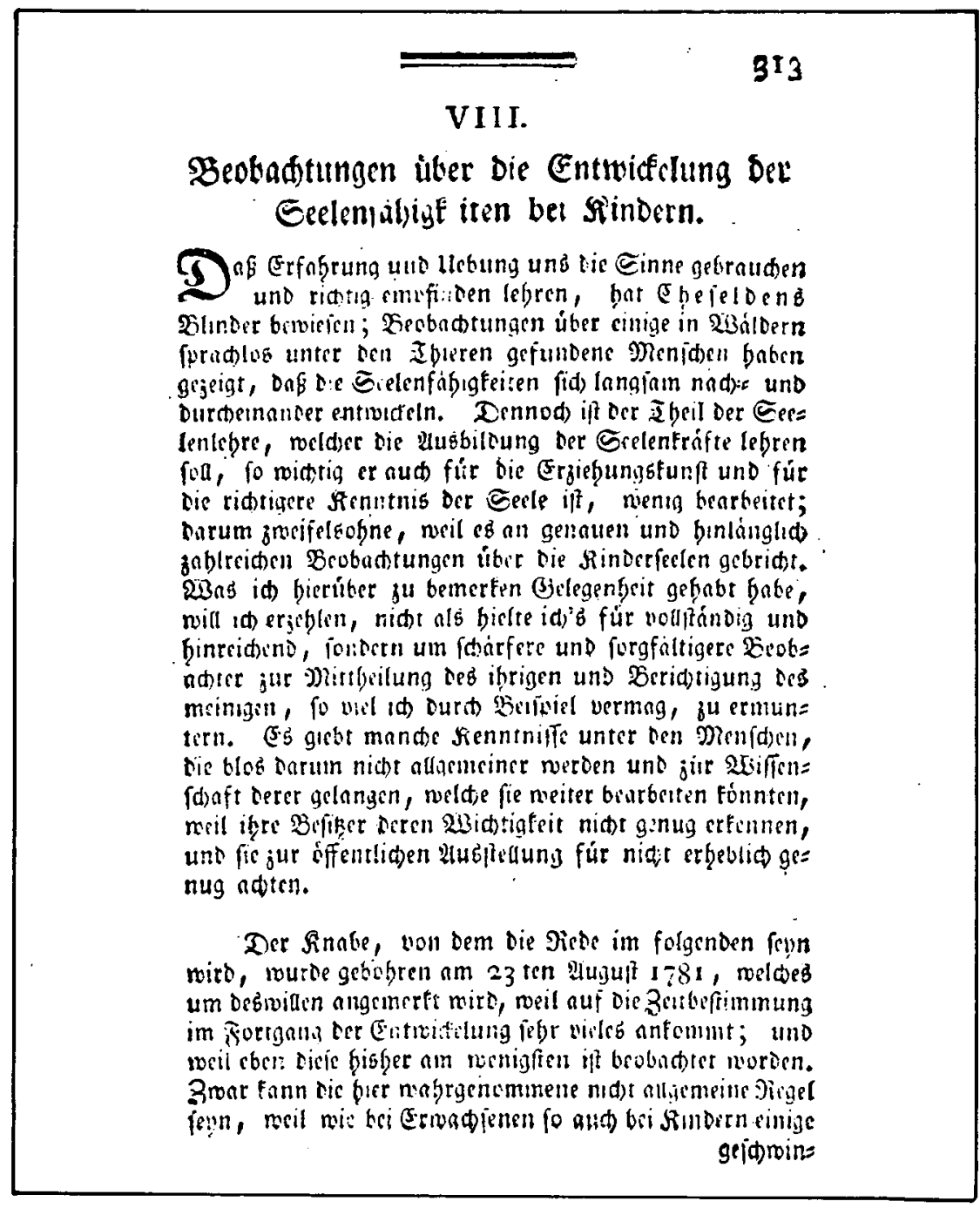

¿Beobachtungen über die Entwicklung der Seelenfähight iten bei Kindern» Hessische Beiträge zür Gelehrsamkeit und Kunst 2 (1987): 313-333; 486-502.

Agradecimientos: Agradecemos al Instituto Alemán de Madrid el habernos procurado una fotocopia del texto original.

(C) 1988 de la traducción Juan Carlos Gómez e Infancia y Aprendizaje.

(C) del texto de las notas Juan Carlos Grmez y Juan Delval. ISSN 0210-3702 
[1] El ciego de Cheselden ${ }^{1}$ ha demostrado que son la experiencia y el ejercicio los que nos enseñan a utilizar los sentidos y a experimentar las sensaciones de forma correcta. Observaciones sobre algunos seres humanos encontrados en los bosques viviendo entre animales y carentes de habla ${ }^{2}$ han mostrado que las facultades anímicas se desarrollan lentamente, de forma sucesiva y unas en relación con las otras. Sin embargo, aquella parte del estudio del alma que se ocupa de la formación de las facultades anímicas, y que tan importante es para el arte de la educación y para un mejor conocimiento del alma, se encuentra poco elaborada. No cabe duda de que ello se debe a la carencia de observaciones precisas y en número suficiente sobre el alma de los niños. Voy a exponer las observaciones que a este respecto he tenido ocasión de hacer, no como si las tuviera por perfectas y suficientes, sino con el fin de que, en la medida en que puedan servir de ejemplo, animen a observadores más agudos y minuciosos que yo a dar a conocer las suyas y rectificar las mías. Hay muchos conocimientos entre los hombres que no llegan a hacerse generales ni alcanzan la ciencia de quienes podrían elaborarlos más, simplemente porque sus poseedores no conocen su verdadero valor y no estiman que sean lo suficientemente importantes como para sacarlos a la luz.

[2] El muchacho del que vamos a hablar a continuación nació el 23 de Agosto de 0;0(1) 1781, lo que hago constar porque la determinación del tiempo en los avances del desarrollo es algo muy importante y porque, hasta ahora, ésta no ha sido observada nada más que mínimamente. Ciertamente, lo aquí observado no puede ser una regla general, ya que, al igual que ocurre con los adultos, en el caso de los niños hay unos que avanzan más rápidamente y otros que lo hacen con mayor lentitud. Sin embargo, sí nos permite conocer aunque sólo sea una de las velocidades posibles y, por lo tanto, definir un poco lo que hasta ahora había permanecido completamente indefinido. Si dispusiéramos de más observaciones de este tipo, podríamos, mediante su comparación, extraer una estimación media del curso normal que sigue la naturaleza ${ }^{3}$. Como es sabido, los niños, justo al principio de sus vidas y, posteriormente, siempre que se despiertan, vuelven sus ojos hacia la luz, lo que demuestra que la luz tiene un efecto agradable en sí mismo que los adultos normalmente han dejado de experimentar, porque el hábito y la presencia de impresiones más vivas hacen que pase desapercibido. Sin embargo, los adultos pueden notar dicha impresión si reparan en el efecto que tiene sobre el alma un rayo de sol filtrado entre las nubes negras de un cielo nublado.

[3] Al día siguiente, cuando la mujer que le cuidaba le metió un dedo en la boca, 0;0(2) el niño se puso a chupetearlo, pero no lo hizo de forma persistente, sino como besuqueándolo. En cambio, cuando se le metió en la boca algo dulce envuelto en un trapo, se puso a succionarlo de forma persistente. Me parece que esto es una prueba de que el acto de mamar no es innato, sino aprendido ${ }^{4}$. El primer movimiento de los labios en esa acción de besuqueo es una reacción mecánica de la boca provocada por las sensaciones de hambre y sed unidas a la excitación de las glándulas por un cuerpo extraño. Pero esto no es todavía una acción de mamar. Sin embargo, tan pronto como percibe que mediante ese movimiento de la lengua afluye una nueva sensación que alivia la molestia que le asaltaba previamente, el movimiento se ve reforzado, y lo que era una acción de chasqueo o besuqueo, a medida que los órganos van adoptando paulatinamente la posición necesaria para la succión, se transforma en un acto normal de mamar. El siguiente hecho sirve para confirmar lo que acabamos de decir: cuando se aplaca el hambre y la sed de los niños con líquidos antes de que hayan tenido oportunidad de mamar, después ya no quieren hacerlo, y resulta muy difícil acostumbrarles a que tomen el pecho. Ello se debe, sin duda, a que no saben utilizar adecuadamente los labios y la lengua y, como, al poder acallarla de otra manera, no se ven presionados por el hambre, tampoco quieren prestarse a usarlos.

[4] Los ojos se movían en todas direcciones, pero no de forma errante y vaga, sino como si buscasen objetos. Las primeras cosas sobre las que se detienen son objetos en movimiento. Pero hay que tener en cuenta que cualquier cosa que se mueva, al provocar en nosotros una serie regular de cambios y modificaciones, es lo que más atrae a los sentidos. Por eso mismo es por lo que el movimiento es lo que más distrae a las personas 
puramente sensoriales. Antes de que la reflexión y el pensamiento encuentren también ocupación en los objetos estáticos gracias a un movimiento interior autoactivo, estos son muy poco observados. Así, pues, es lógico que tengan que ser los objetos móviles los que atraigan primordialmente al alma del niño. En esto, en mi opinión, puede verse cómo el rasgo distintivo del ser humano aparece ya en el alma infantil. Los animales, incapaces de encontrar distracción en cualquier otra cosa, atienden sólo a aquello que satisface sus necesidades físicas. En consecuencia nunca se verá que un animal siga con sus ojos de forma persistente algo que no esté relacionado con sus necesidades corporales. En cambio, el hombre, destinado a más altas metas, trata desde el primer momento de ampliar sus representaciones ${ }^{6}$ con independencia de sus necesidades corporales, y encuentra distracción incluso allí donde sus apetitos sensoriales no le empujan. La razón de esto reside sencillamente en un grado superior de actividad y una intensa autoactividad, que buscan ocupación sin cesar y hacen que siga mostrándose activo aún después de que sus necesidades físicas hayan encontrado satisfacción.

[5] El niño se encontraba a gusto sin nada encima y sólo se le podía fajar ${ }^{5}$ a disgusto y con evidente resistencia por su parte. Sin embargo, no había nada intencional en el movimiento de sus miembros, fuera de una especie de sensación de dolor que hacía que el cuerpo se inquietase sin ningún tipo de volición ni propósito. La mayoría de las veces, el movimiento del cuerpo sirve para aliviar el dolor al desviar la atención de esta sensación. Por otra parte, en la mecánica corporal existe una tendencia irreprimible a moverse tan pronto como sentimos un dolor vivo. También los niños mueven involuntariamente sus cuerpos ante el dolor en virtud de este mecanismo. El motivo por el que los niños se encuentran a gusto cuando están libres y a disgusto cuando están enfajados es, en parte, el mecanismo que acabamos de mencionar y, en parte, el hecho de que el movimiento proporciona también ocupación y distracción. Además del dolor, existen otras causas capaces de poner al cuerpo en movimiento de forma instintiva: la acumulación de la sangre y de los humores en ciertas zonas, la circulación demasiado libre de los humores en general, determinadas estimulaciones en ciertas zonas, son agentes que despiertan sensaciones oscuras y provocan esfuerzos involuntarios por moverse.

[6] ¿Pero son todos los movimientos de los niños a esta edad involuntarios? ¿Sería posible que en este momento de la vida interviniese ya algún propósito o algún conocimiento adquirido? Hay una circunstancia que, en mi opinión, demuestra que ya a esa edad puede aceptarse la existencia de algo aprendido. La madre no podía aún administrar al niño el alimento con que se encuentra dotada por la naturaleza. No se quiso acostumbrar al niño a ingerir alimentos líquidos por la razón anteriormente explicada, de manera que se vio expuesto a pasar una cierta necesidad e incluso, como era un niño sano y robusto, un poco de hambre. Con el fin de aliviarla, el niño intentaba introducirse en la boca su propio dedo o, si podía apoderarse de él, el de otra persona, para, a continuación, ponerse a chupar. Sin embargo, sólo conseguía encontrar la boca después de un esfuerzo prolongadamente infructuoso. A mi entender, en este ejemplo, puede apreciarse ya algo aprendido, algo voluntario. El niño ha llegado a saber ya por experiencia que, cuando se introduce algo en la boca, la sensación de hambre se alivia. Ambas representaciones se encuentran ya asociadas. Asimismo, ya ha sido capaz de distinguir el lugar de su cuerpo en el que se sienten primordialmente las sensaciones de hambre y de sed, e intenta mover hacia él las manos. Sin embargo, al carecer de una representación más clara de su cara y por falta de experiencia en el movimiento de los brazos y de las manos, no era todavía capaz de encontrar el lugar adecuado. Ciertamente, el niño aún no sabía agarrar cosas voluntariamente. Esto sucedía gracias a un mecanismo puramente instintivo, mediante el cual los dedos actuaban igual que sucede en ciertas plantas sensibles que cierran sus hojas o sus flores tan pronto como son tocadas en su interior por un cuerpo extraño.

0;0(3) [7] Todavía no existía la sensación de cosquillas. Tan pronto como se le tocaban suave. mente las plantas de los pies, estos se retraían, pero sin la expresión de risa ${ }^{7}$. Tampoco podía observarse ni en sus ojos ni en la contracción de la boca nada que guardase alguna relación con las expresiones de dolor o alegría. Así, pues, en el niño aún no se habían 
diferenciado las impresiones. Todo era experimentado por él como una impresión global que poseía simplemente un carácter general atractivo o repulsivo, sin hacer una distinción más específica entre las categorías de lo agradable y lo desagradable. Ni siquiera conocía aún las distintas clases de sensaciones gustativas, que deberían de ser las primeras en diferenciarse, y aún menos las sensaciones olfativas. La comprobación de este hecho tuvo lugar el día 25 de Agosto. Como consecuencia de una indisposición sobrevenida, se prescribió al niño una medicina que no era precisamente agradable y que despedía un fuerte olor; el muchacho, sin embargo, la tomó sin oponer la menor resistencia, como si fuera su alimento habitual. Así, pues, incluso las sensaciones más sencillas y que nos resultan más fáciles de distinguir requieren del ejercicio y la comparación para ser discriminadas y representadas de forma definida ${ }^{8}$.

[8] El 28 de Agosto aparece la expresión de risa, pero sin que exista ningún motivo 0;0(6) para ello. Por lo tanto, lo más probable es que sea una sonrisa producida de forma involuntaria, sin ningún sentimiento de regocijo, simplemente porque el mecanismo se puso en marcha accidentalmente. Es frecuente que los niños adopten esta expresión mientras duermen o cuando están a punto de dormirse, lo que indica que lo hacen sin pensamientos ni sentimientos correspondientes. Asimismo, es frecuente que los niños pequeños, mientras duermen, hagan otros movimientos y emitan sonidos como si estuvieran soñando. Pero cabe presumir con toda certeza que no están soñando, sino que se mueven por estímulos puramente corporales. Yo, cuando menos, no he observado nada a partir de lo cual pueda inferirse con un mínimo de certeza la existencia de representaciones de objetos ausentes. Incluso las asociaciones sensoriales sólo hacen su aparición en el niño más adelante. Las cuidadoras, las amas de cría e incluso las madres suelen tomar estos movimientos por sueños, pero es que ellas no saben distinguir entre los efectos mecánicos y los efectos de origen anímico, y atribuyen estos últimos a cualquier cosa que guarde semejanza con ellos o que en los adultos surja habitualmente de estos.

[9] El día 5 de Septiembre, es decir, 13 días después de su nacimiento, el niño mostró $0 ; 0$ (14) los primeros indicios de representaciones adquiridas, con sensaciones y sentimientos anímicos más claros. Empezó a tomar de mala gana algunas medicinas, dando muestras evidentes de oposición y llegando incluso a escupirlas. Sin embargo, esto no sucedió desde el primer momento, sino después de que las hubiese probado unas pocas veces. Así, pues, en ese momento el niño era ya capaz de distinguir entre el sabor de las medicinas y el de su alimento habitual, y también sabía, quizás gracias al olfato o por la forma inhabitual de administración, si se le iba a dar algo desagradable o un alimento. Sin embargo, esta discriminación era aún bastante imprecisa, ya que más tarde se tomó la misma medicina sin ninguna resistencia. También ese día, empezaron a verse en sus ojos y gestos faciales expresiones de dolor y alegría, cuando anteriormente los ojos no decían absolutamente nada y la boca no era capaz de ningún movimiento parecido al de ir a llorar. Antes, todos los objetos eran contemplados de la misma forma. Ese día, en cambio, pudo observarse una atención sostenida hacia los gestos de la persona que le hablaba, y, además, por otra parte, el hecho de hablarle cuando se ponía a llorar empezó a surtir efecto. Antes, lloraba por dolor; ahora, también lloraba cuando las manipulaciones a que se le sometía le resultaban incómodas. Todo esto significa que ya existían en él representaciones reunidas, que era capaz de distinguir entre los seres humanos semejantes a él y los demás objetos, y que poseía una discriminación más precisa de las sensaciones. El primer trimestre de vida se suele conocer con el nombre de atrimestre tonto ${ }^{9}$. Esto sería cierto en la medida en que es al cabo de esos tres primeros meses cuando hacen su aparición los vestigios más claros de sensaciones y representaciones humanas. Pero no lo sería si lo que se pretendiese decir es que antes de ese momento no puede observarse el menor atisbo de ellas.

[10] El día 10 de Septiembre, pudimos volver a observar todo esto de forma mucho 0;0(19) más definida y en circunstancias nuevas. Si, cuando el niño se ponía a llorar, le colocábamos en la posición de mamar o le pasábamos suavemente una mano por la cara, se callaba y buscaba los pechos. En este hecho es visible la existencia de asociación de ideas. La sensación de una posición determinada o la de la mano acariciándole suavemente 
despertaban en él la representación de mamar y de los pechos maternos. De manera que el niño se había formado ya una representación definida de ambas cosas; es decir, había conservado vestigios de unas sensaciones fuertes, que se renovaban ante una estimulación sensorial dada y que, en virtud de una facultad anímica interna, terminaron por convertirse en representaciones. Así, pues, había discriminado hasta tal punto entre distintas impresiones sensoriales que ya era capaz de representarlas de forma separada. Sin embargo, las representaciones de su propio cuerpo y de las distancias eran, por una parte, imperfectas y, por otra, totalmente inexistentes. Imperfectas, porque cuando se le fueron dejando las manos libres por cortos períodos de tiempo, se golpeaba y se arañaba con ellas hasta causarse dolor. No distinguía, por lo tanto, entre su propio cuerpo y un cuerpo ajeno, ni sus propios miembros de otros. Totalmente inexistentes, porque no sabía nada de las distancias; si no, no se hubiera golpeado en el rostro ni hubiera seguido haciéndolo incluso después de varios intentos. También a partir de esa observación podía comprobarse que era capaz de controlar los movimientos de sus miembros en muy escasa medida, y que aún era menos capaz de prestar el grado adecuado de fuerza a sus movimientos. Por otra parte, no podía observarse ningún atisbo de voluntariedad en los movimientos de las manos, salvo quizás el hecho de que al sentir hambre se las llevaba a la boca para chupárselas, lo que, sin embargo, sucedía más a causa de excitaciones mecánicas ligadas a alguna asociación de ideas, que por un propósito preconcebido propiamente dicho. Los primeros movimientos corporales son puramente mecánicos, provocados por excitaciones físicas, y mediante ellos obtiene el alma más tarde representaciones de los movimientos que pueden producirse con los miembros; entonces hacen su aparición los apetitos o deseos que, con ayuda de la asociación, forman los movimientos voluntarios; la experiencia, por su parte, enseña a conocer las distintas clases de movimientos y a encauzar la fuerza hacia las extremidades pertinentes, y sólo entonces somos capaces de poner en movimiento cada miembro en adecuada consonancia con cada propósito.

$0 ; 1(5)$ [11] El día 28 del mismo mes, se pudo observar que el niño ya no se golpeaba tan frecuentemente con las manos ni se arañaba. La repetición frecuente de una experiencia dolorosa le había enseñado, por consiguiente, a establecer una cierta diferenciación entre él mismo y los demás cuerpos y a conocer con mayor precisión algunas distancias. Por lo tanto, esto confirma lo que Cheselden había observado en su ciego, a saber, que la vista por sí sola no puede aprender nada sobre las distancias, al aparecer todos los objetos como si estuviesen sobre el ojo, y que, por consiguiente, es preciso que el tacto acuda en ayuda de la vista para formar representaciones de las cosas que se encuentran alejadas o están situadas fuera de nosotros. Sin embargo, tengo mis dudas sobre si los niños no podrían adquirir antes el conocimiento de las distancias y una mejor utilización de las manos. Con la práctica de envolver desde el principio las manos de los niños, no cabe la menor duda de que les estamos impidiendo que mediante sus propios movimientos desarrollen antes ideas sobre su propio cuerpo y sobre las cosas externas a él. También por aquella época pudo observarse que el sueño disminuía. Como es sabido, los niños sanos duermen casi durante todo el día, siendo sólo despertados por el hambre; pero el sueño va disminuyendo cada vez más, de manera que llega un momento en que, cuando queremos dormirlos, ya no se dejan calmar. ¿A qué se debe esto? ¿Es por causas puramente corporales o se debe a la existencia de una mayor actividad del alma? Lo primero parece muy difícil. Los animales, cuando tienen suficiente alimento y, por lo tanto, no son puestos en acción ni por el hambre ni por la sed, duermen durante todo el día. Un perro, que en otras circunstancias se muestra tan vivaz, yace tumbado e inmóvil en su sitio tan pronto como no hay ninguna necesidad corporal que le ponga en movimiento. Es cierto que las aves enjauladas no duermen durante el día, pero es que el alimento se les suministra de tal manera que sólo pueden tomarlo en cantidades sumamente pequeñas, con lo cual nunca pueden saciarse por completo. Además, parece que en las aves la digestión se produce con mayor rapidez. No sucede así ni en el hombre ni en el niño. En efecto, ambos pueden quedarse saciados durante varias horas con una sola comida. Así, pues, esa progresiva disminución del sueño procede 
de un aumento de la actividad anímica. Cuantas más representaciones reúne la joven alma, en mayor actividad se ve envuelta y tanta menos quietud concede al cuerpo. ¡Otra prueba más de la mayor actividad natural del intelecto humano! También en esta fecha se observaron por vez primera sonrisas provocadas por una sensación anímica. En efecto, cuando se le hablaba con palabras de ánimo o se ensayaban frente a él distintas expresiones faciales, el niño sonreía. No es fácil determinar qué era lo que le resultaba agradable de estas actividades. ¿Era quizás la variabilidad y diversidad de los movimientos? ¿Se trataba de los comienzos de la simpatía o quizás era solamente lo inesperado de los movimientos que se sucedían con tanta rapidez? ¿Se trataba quizás de todos estos factores juntos? El siguiente hecho parece confirmar que el papel de la simpatía en el fenómeno anterior no es pequeño: cuando le hablábamos, el niño intentaba a su vez producir sonidos, ciertamente sencillos y carentes de articulación, pero variados. El impulso [Tr:eb] de imitación se desarrolla pronto, y parece tener su fundamento originario en un mecanismo que es ayudado por la asociación de ideas. Siempre que nos representamos vivamente algo y contemplamos con profunda atención un movimiento efectuado por otra persona, no podemos por menos que copiarlo según nuestra capacidad, y experimentamos un fuerte estímulo, que frecuentemente sólo podemos resistir con mucho trabajo y que sólo la reflexión es capaz de reprimir, para hacer exactamente lo mismo. La razón de ello reside, en parte, en la organización misma del organismo, ya que los órganos que causan la representación viva se colocan precisamente en la posición en que deben de estar para ejecutar la acción de que se trate; y, en parte, se debe también a la asociación de ideas, ya que las representaciones de las acciones tienen como acompañantes inmediatas a las acciones mismas y constituyen su punto de partida originario. Por eso es por lo que los niños que ya han aprendido a producir sonidos y saben mover los órganos de la voz son estimulados involuntariamente a imitar. Aquí radica precisamente la primera base de la simpatía. En efecto, al contemplar a otra persona animada por una sensación cualquiera, el alma adopta la misma postura en la que anteriormente había experimentado lo mismo y, de esa manera, se renueva esa antigua sensación. Así, pues, el niño, que ya había reunido algunas representaciones sobre sensaciones agradables y desagradables, con independencia de que aún no conociese sus expresiones faciales correspondientes o tuviera ya alguna idea de ellas, al contemplar la cara alegre del otro se veía impelido a sonreír, simplemente porque la contemplación de esa expresión le había colocado internamente en la condición propia de esas sensaciones. Entre las expresiones faciales y las sensaciones existe una relación natural, según la cual la misma sensación siempre va acompañada por la misma expresión. Por eso, bastará con que se haya producido previamente una sensación determinada u otra parecida a ella para que su expresión correspondiente evoque esa sensación, aun cuando no se haya tenido ocasión de conocer previamente la expresión en cuestión. Los cambios rápidos que se producen en las expresiones faciales tienen también su parte de causa a la hora de provocar el efecto de la sonrisa: al principio, los niños sonríen ante todo lo que cambia de forma repentina e inesperada, aun cuando la cosa en sí no tenga nada de graciosa. Esto demuestra que lo inesperado, en sí mismo y excepción hecha de lo que produce miedo, produce una sensación agradable.

[12] Algunas sensaciones empiezan ahora a separarse de forma precisa y segura, espe- 0;1(9) cialmente las del gusto. En efecto, el día 2 de Octubre la medicina es siempre tomada con muestras evidentes de resistencia. Por otra parte, el niño distingue las cosas externas a él de sí mismo, como se ve en sus primeros esfuerzos por coger algo extendiendo las manos y doblando todo el cuerpo hacia adelante. Sin embargo, todavía no sabía usar los dedos para agarrar voluntariamente las cosas, y si cogía algo era más por casualidad que por haber ejecutado adecuadamente una volición: porque el objeto en cuestión, accidentalmente, había quedado entre sus dedos de tal manera que podía ser agarrado. ¡Cuánto ejercicio y cuántos intentos infructuosos no requerirán, por tanto, esos movimientos que consideramos como los más fáciles y casi innatos! También ahora son claramente visibles los esfuerzos del alma para fabricar representaciones a partir de las sensaciones; con anterioridad, ningún objeto era seguido durante mucho tiempo. Con la apa- 
rición de un objeto nuevo, cualquier objeto era pronto perdido de vista. En cambio, ahora los objetos eran seguidos por la mirada del niño durante largo rato, y podía observarse en los ojos la existencia de un esfuerzo interno por comprender correctamente las imágenes.

$0 ; 1(24) \quad$ [13] El 19 de Octubre, habían cesado ya por completo los golpes de las manos en el rostro y los arañazos. Esto es indicio de que el cuerpo propio se distinguía ya con precisión de los ajenos, de que habían empezado a reconocerse las distancias, por lo menos en el caso de objetos muy próximos, y de que había aprendido un cierto grado de control voluntario sobre las manos y los brazos. Los esfuerzos por reunir representaciones eran más evidentes; en efecto, ahora sólo seguía con los ojos durante largo rato los objetos nuevos que no había visto con anterioridad. También se desarrolló con mayor claridad la sensación interna de lo agradable de la propia actividad, que se ponía claramente de manifiesto en el evidente placer con que contemplaba objetos nuevos, especialmente si estaban en movimiento. El muchacho contemplaba ahora los gestos de quienes le hablaban con mayor esfuerzo, igualmente con el fin de aprender a partir de ellos sus actitudes hacia él, y que el muchacho ya era capaz de comprenderlas parcialmente quedaba patente por el hecho de que se le podía calmar hablándole dulcemente y en tono compasivo. Los niños, gracias a sus experiencias cotidianas, aprenden fácilmente a darse cuenta de la influencia que las demás personas tienen sobre ellos. No tiene nada de extraño, por consiguiente, que a partir de ese momento presten atención preferente a la gente, con el fin de averiguar los sentimientos que tienen hacia ellos. Hasta ahora, cuando algo le resultaba desagradable, el muchacho lo ponía de manifiesto simplemente llorando y resistiéndose, pero nunca había hecho uso de la fuerza para alejar de sí la cosa que le resultaba desagradable. Ahora, sin embargo, como se sentía más fuerte y era capaz de discriminar con mayor precisión lo desagradable así como de sentirlo de manera más viva, ponía claramente de manifiesto esa fuerza de rechazo mediante la cólera. A esto hay que añadir que ya sabía por experiencia que muchas incomodidades le eran infligidas por los hombres, y que estas podían eliminarse mediante una enérgica resistencia, de lo cual anteriormente no existía la menor representación. Los niños se dan cuenta muy pronto de la impresión que sus gritos causan sobre los demás. Al principio, intensifican su llanto exclusivamente como consecuencia de un aumento en la sensación de dolor pero, cuando descubren que la ayuda les llega con mayor rapidez, tanto más aumentan el volumen de sus gritos. De manera que, a partir de entonces, empiezan a gritar sencillamente por el enojo que les produce el no ser complacidos de inmediato. Esto, me parece, constituye el punto de partida de la cólera, cuyo primer aspecto consiste en un mayor esfuerzo por rechazar lo que resulta molesto así como una sensación más fuerte de molestia. La otra vertiente de la cólera consiste en intentar hacer que los demás se den cuenta de la sensación de aflicción que nos ha sido causada, y asustarles mediante la emisión de sonidos y la adopción de posturas intimidadoras. A eso se debe el que los niños, cuando aún no saben que muchas de las cosas que les molestan dependen de la voluntad de los demás, se limiten a emitir vocalizaciones lastimeras, pero que, tan pronto como han aprendido a atribuir sus incomodidades a los demás, empiecen a producir vocalizaciones con un grado mayor de irritación. Por eso ahora, nuestro muchacho, cuando su llanto no era atendido de inmediato, empezaba a proferir un grito encolerizado.

$0 ; 2(18)$ [14] Cuanto mayor es el grado de diferenciación de las sensaciones individuales, con mayor fuerza es experimentada cada una. Al mismo tiempo y por la misma razón, se van reforzando los grados de las sensaciones hasta que terminan por convertirse en emociones. Las sensaciones agradables se expresaban cada vez con más fuerza y, por vez primera, se observaron accesos de alegría. La contemplación de la luz, sobre todo la del atardecer después de un período de oscuridad precedente, que hasta entonces se había limitado a provocar atención, empezó a despertar una evidente alegría. La sontisa había sido anteriormente una expresión de satisfacción, ahora, después de que la sensación se hubiera intensificado, apareció en su lugar la carcajada. Por eso, en esta época, los movimientos que cambiaban de forma rápida, ya fueran de su propio cuerpo o del de los demás (por ejemplo, saltar o dar brincos), provocaban carcajadas. También entonces, 
empezó a manifestarse la sensación de cosquillas, pero sólo en la barriga y nunca en las plantas de los pies, esto prueba que, para poder ser experimentada en toda su singularidad, esta sensación también requiere de la comparación con otras y de la construcción de otras sensaciones, y que ni lo agradable ni lo desagradable son inicialmente sentidos de forma distinta y determinada. En esta fecha (estábamos a 10 de Noviembre), empezaron a salirle los dientes. La consiguiente sensación de dolor en la boca provocó y favoreció el desarrollo de nuevas representaciones y capacidades. Con anterioridad, las manos habían sido muy poco utilizadas, puesto que no había ningún motivo o estímulo especial para ello. Si, no obstante, algo llegaba a ser cogido por las manos del niño, no era sujetado durante mucho tiempo, ya que la mera acción de tener cogido algo no le proporcionaba ocupación ni entretenimiento suficientes. Lo que más utilizaba eran los ojos, al ser éstos los órganos que proporcionaban las ideas más variadas y cambiantes al intelecto. Sin embargo, ahora que el dolor de su boca exigía alivio constante, no sólo empezaron a moverse los dedos de forma habitual hacia la boca, sino que también todo lo que caía en sus manos era conducido a ella con el fin de aliviar y distraer el dolor mordiéndolo. De esta manera, el muchacho aprendió por ver primera a agarrar algo, aunque su acción tampoco duraba mucho, ya que lo que había agarrado no tardaba en ser soltado de nuevo. Esto no sucedía por hastío, ya que la cosa en cuestión volvía a ser inmediatamente agarrada con ganas, sino por inexperiencia. En efecto, el niño no tenía aún los dedos bajo su control; todavía seguían cerrándosele de forma casi puramente mecánica y se volvían a abrir de la misma manera, a pesar de que el objeto que tenían cogido debería de seguir en su poder. El niño no agarraba aún cosas alejadas o que por cualquier otro motivo no llegasen a sus manos, presumiblemente porque aún no había aprendido por experiencia que con las manos podemos obtener algo alejado y porque carecía de cualquier representación clara de la prensión manual de los objetos. Cuando los niños todavía no han aprendido que pueden acercar los objeros con ayuda de sus manos, se esfuerzan por acercarse ellos mismos a los objetos, inclinando hacia adelante y extendiendo mecánicamente sus brazos. La razón de este hecho parece residir en la manera en que originalmente se encuentra organizada nuestra naturaleza: en efecto, siempre que surge en nosotros un deseo orientado hacia algo alejado, experimentamos una tendencia a inclinar el cuerpo hacia adelante, cuya consecuencia posterior es la extensión de las manos. Por eso, siempre que la reflexión nos prohíbe agarrar algo, no podemos evitar de todas formas efectuar, al menos, ese primer movimiento.

[15] El día 25 de ese mismo mes, el niño ya agarraba las cosas cercanas que se encon- $0 ; 3$ (2) traban delante de él y comenzaba a darse cuenta de que también ellas podían convertirse en un medio para procurarse distracción y adquirir nuevas representaciones. Al principio, los niños no juegan con nada. Lo que no se llevan a la boca para ser mordido u obtener con ello una sensación gustativa es soltado inmediatamente. Los niños ejercitan preferentemente la vista y el gusto. Sin embargo, tan pronto como con ayuda del sentido de la vista, ya ejercitado, y una conexión más estrecha entre las ideas visuales y táctiles que deriva de la utilización de las manos, se percibe que éstas son un instrumento para la adquisición de representaciones nuevas, y especialmente un medio de provocar esos movimientos que tan entretenidos y agradables le resultan, un medio de acercar los objetos a la vista y al gusto, las manos son más ejercitadas y los niños empiezan a jugar con las cosas que se les ponen delante. También de esa manera aprenden los niños a utilizar las manos para conseguir objetos alejados, cuando, al principio, sólo cogían lo que por sí mismo venía a caer entre sus dedos. Algunas de las sensaciones habituales estaban ahora más diferenciadas y se habían convertido en representaciones. De esta manera, entonces se observaron también más y mejores ejemplos de asociación. Cuando estaba en el regazo, el muchacho se orientaba hacia el lado de los pechos, aunque estos estuvieran cubiertos. Si veía a alguien beber, hacía con los labios un movimiento como si él también estuviera degustando algo. Así, pues, era capaz de distinguir la boca de otra persona, como la suya propia, y sabía que éste era el asiento del sentido del gusto o el instrumento mediante el que se consume el alimento. A través de las manos, el tacto le había proporcionado la idea de lo que era una boca y la semejanza le había 
dado la otra, a saber, que en los demás la boca sirve para las mismas acciones. También entonces, se observó el primer indicio verosímil de ensueños: mientras dormía, hacía movimientos con la boca como si estuviera mamando. Probablemente, una excitación en el estómago o.en la boca despertaba la sensación de hambre o de sed, y ésta provocaba los movimientos de succión de la boca, de manera que el niño soñaba que estaba mamando del pecho.

$0 ; 3(6) \quad[16]$ El aumento del dolor de dientes incrementó la necesidad de recurrir a todo tipo de cosas con el fin de morderlas; por eso empezó también a desear cosas alejadas con el fin de llevárselas a la boca. En efecto, las representaciones sobre las distancias se fueron desarrollando cada vez más, y sus experiencias también le fueron enseñando paulatinamente que las cosas que están alejadas pueden acercarse. Lógicamente, los niños, al principio, no tienen ninguna noción de que lo que se encuentra alejado o bien puede ser acercado a ellos o bien ellos mismos pueden acercarse a la cosa en cuestión, para que su deseo se vea satisfecho. El niño no sabía aún de forma clara que las manos son un medio que puede utilizarse con este fin. En efecto, intentaba coger las cosas alejadas con la boca, en lugar de llevárselas a la boca con las manos. Esto sucedía el 29 de Noviembre.

0;3(7) [17] El día 30, oyó por vez primera cómo tocaba alguien el piano, reaccionando con extrema alegría y viveza. Así, pues, el sonido, por sí mismo, sin conocimiento de la melodía o de los sentimientos que se expresan a través de él, produce una impresión agradable.

0 ;4(7) [18] Hasta el 30 de Diciembre, no se observó nada que mereciese la pena consignar. Pero, ese día, empezó a ponerse de manifiesto que el niño quería servirse ya de sus manos para sustentarse. Si, sujetándole de los brazos, le dejábamos caer hacia abajo desde una altura desacostumbrada, hacía esfuerzos por agarrarse de algo con las manos para no caerse, y le resultaba desagradable que le subiesen demasiado alto. El todavía no podía tener ninguna noción de lo que es una caída, de manera que su miedo no podía ser más que una impresión puramente mecánica del mismo tipo que la que experimentan los adultos cuando se encuentran subidos a un lugar alto e inhabitualmente escarpado, algo parecido a la sensación de vértigo. El muchacho se apartaba de las personas vestidas de negro con signos evidentes de aversión. El negro, por consiguiente, como color de las tinieblas, debe de tener de forma natural algo desagradable, lo que también aclararía el que este color se utilice prácticamente siempre para vestirse en ocasiones desgraciadas. Por la fuerza del hábito una cosa que es desagradable acaba por sentirse menos, y uno acaba por persuadirse de que ese desagrado no existe en absoluto. Durante esta época, el niño aprendió la utilización de las manos para aproximar cosas. El niño intentaba entonces coger todo, pero aún le hacía falta más ejercicio. En lugar de coger directamente la cosa en cuestión, se veía obligado a extender varias veces los brazos antes de conseguir llevarlos al lugar adecuado, y, una vez allí, aún tenía que hacer más intentos hasta conseguir colocar los dedos de la manera apropiada para coger el objeto. Por una parte, los dedos aún no estaban lo suficientemente ejercitados en la acción de coger y, por otra, aún no sabía hacer con sus manos todos los movimientos necesarios para ser capaz de hacer lo que convenía a sus propósitos; finalmente, por otro lado, no parecía poseer aún ninguna representación plenamente correcta de la distancia y de la posición. A partir de ahora, el que una persona cantase le llamaba siempre la atención, y era acompañado con saltos y movimientos de los brazos como signos de alegría. Así, pues, lo que le impresionaba seguía siendo exclusivamente el sonido. Las sensaciones gustativas se habían diferenciado ya de forma bastante precisa. Se resistía con todas sus fuerzas a ingerir un medicamento un poco amargo; en cambio, aceptaba de buen grado vino y otras sustancias alimenticias. También entonces se puso de manifiesto la actividad inherente al alma humana, que se encontraba ya en un grado más avanzado, en su efecto más característico: el aburrimiento. Si se le apartaba de toda sensación atractiva, el muchacho se mostraba inquieto y empezaba a llorar. Algo nuevo, un pequeño cambio, volvía a ponerle contento y le hacía olvidar incluso sus, muchas veces, intensos dolores de dientes. También entonces empezó a ejercitar los instrumentos del habla produciendo 
todo tipo de sonidos, incluso sin haber sido animado a ello. Sin embargo, aún no intentaba imitar ningún sonido, ni siquiera cuando se decían ante él con ese propósito, lo que presumiblemente se debía a que aún no poseía ninguna idea clara sobre la diversidad de los sonidos, especialmente de los articulados, y a que aún no era capaz de mover los órganos del habla de forma voluntaria y premeditada. Es evidente que los niños pasan largos períodos de tiempo ejercitándose en la producción de sonidos sencillos inarticulados y también algunos sonidos articulados simples, con el fin de obtener representaciones claras de ellos, antes de que sean capaces de imitar estos mismos sonidos, y que, al igual que sucede con las manos, los órganos del habla también necesitan de una preparación previa mediante una gran cantidad de ejercicio, antes de que los niños sean capaces de producir sonidos previamente ejecutados o ejemplificados ante ellos.

[19] El día 31 de Diciembre, se pudo observar cómo el niño volvía sistemáticamente $0 ; 4(8)$ la vista hacia el lugar del que procedía el sonido de una campanilla que había escuchado. Así, pues, ya había aprendido a distinguir lo que era escuchado propiamente por el oído derecho y por el izquierdo. Asimismo, se había acostumbrado a representarse, de forma hasta cierto punto definida, los lados en relación a su cuerpo. Esto demuestra cuánto tiene que trabajar el alma para obtener distinciones aún más sutiles, basadas casi exclusivamente en las comparaciones.

[20] La actividad ha aumentado claramente. Desde el momento en que se despertó, $0 ; 4(24)$ sus brazos y sus pies estuvieron en constante movimiento. El alma ansiaba tener en todo momento una distracción y se mostraba inquieta tan pronto como ésta le faltaba. El niño había aprendido ya a reconocer con toda claridad el pecho y mostraba ante su vista una evidente alegría. Esto fue observado el 16 de Enero de 1782.

[21] El día 26 puede reconocerse aún con mayor claridad su creciente curiosidad. La mujer que le cuidaba le sacaba a la calle siempre que el tiempo lo permitía, y esto le causaba una extraordinaria alegría. A pesar del frío, siempre manifestaba vivos deseos por este cambio. A causa de ello, siempre se separaba de mala gana de su nodriza, y prefería estar con ella antes que con su madre, salvo cuando tenía hambre. Pudo observarse entonces claramente con qué rapidez se diferencian y asocian las representaciones una vez puestos en marcha estos procesos. El muchacho no había tardado mucho en darse cuenta de que el hecho de que su nodriza se pusiese el abrigo era señal de que iban salir, y, por ello, se ponía contento siempre que ella se ponía el abrigo, aun cuando en esos momentos estuviese en pleno. llanto. Tampoco había tardado mucho en darse cuenta de que, para salir, la puerta tenía que abrirse; por eso, se echaba hacia la puerta cada vez que la nodriza se acercaba a ella, se ponía contento cuando se abría y se mostraba impaciente cuando volvía a cerrarse. ${ }^{11}$ Por regla general, los niños de esta edad, si son sanos y espabilados, buscan los espacios libres; odian todo espacio cerrado, especialmente el permanecer durante mucho tiempo en la misma habitación. Lo agradable del aire libre, pero sobre todo indudablemente la variedad y diversidad de los objetos y el entretenimiento y cantidad cada vez mayor de conocimiento que gracias a ellos obtiene el alma, son los que provocan este deseo.

[22] Hasta ahora, siempre le había resultado indiferente lo que caía en sus manos, 0;5(15) y sin dar la menor muestra de desagrado se había dejado quitar los objetos con los que estaba jugando. El 7 de Febrero, sin embargo, se aferraba más a las cosas con las que había conseguido hacerse, siempre que no estuviera harto ya de ellas, y lloraba cuando se le quitaba un juguete. También era ya capaz de entretenerse durante un rato jugando completamente solo. Anteriormente, las cosas para él eran simplemente para ser miradas; aún no era capaz de ponerlas en movimiento él mismo. Pero ahora, después de haber aprendido a utilizar las manos, le servían de mayor distracción y, por eso, no le gustaba que le despojasen de ellas.

[23] El 10 de Febrero se observaron expresiones de sorpresa y agrado. Hasta ahora, 0;5(18) las únicas señales de dolor, cólera, impaciencia y alegría habían sido el llanto, la agitación y la risa. En esta fecha, cuando veía algo nuevo y atractivo, emitía la exclamación «aj», que es la señal natural ante una sorpresa agradable. Así, pues, era ya capaz de reconocer lo nuevo con precisión, y experimentaba claramente la impresión de novedad. Tam- 
bién entonces, empezó a hacer uso de los pies para andar; se ponía contento siempre que le sosteníamos sobre sus pies.

[24] También había aprendido a distinguir a las personas y, cuando tenía hambre, de entre todos los presentes, sólo quería estar con su madre. Sin embargo, aún no tenía una representación completamente definida de ella, y aún no era capaz de reconocer por el vestido la diferencia de los sexos: así, si en el momento en que tenía hambre le cogía en brazos una persona de sexo masculino, también buscaba su pecho. Ya había reparado en las diferencias de sonido que existen entre las distintas emociones, especialmente entre el enojo y la satisfacción, puesto que era posible hacerle callar mediante amenazas.

0;6(20) [25] Después de ejercitarse mucho en la producción de sonidos y después de adquirir una cierta destreza en la utilización de los órganos del habla para producir distintos sonidos, el día 14 de Marzo empezó a articular voluntariamente y a imitar sonidos. Su madre decía ante él la sílaba «ma», él miraba atentamente a su boca e intentaba imitar esa sílaba. También se observó que, cuando oía una palabra fácil de pronunciar, movía los labios para imitarla silenciosamente.

0;8(4) [26] El día 27 de Abril descubrimos signos evidentes del afecto que sentía hacia de. terminadas personas y de que estaba familiarizado con ellas, ya que el niño lloraba cuando fingíamos que pegábamos a su madre o a su nodriza. También en esta fecha vimos la más difícil de todas las asociaciones de ideas, que los animales alcanzan sólo en contados casos, y ello después de grandes esfuerzos y nunca por impulso propio: la consumación de la asociación entre la representación y su signo, la palabra. Cuando le preguntábamos dónde estaba esta o aquella cosa de entre aquellas que aparecían cotidianamente y en ese momento estaban presentes, él la señalaba con el dedo. Así, pues, el niño no sólo tenía representaciones claras de las cosas sino también de los sonidos articulados, y sabía además que esos sonidos significaban esas cosas o esas representaciones. Por consiguiente, había asociado estas representaciones tan alejadas entre sí. Por lo tanto, podemos asumir con seguridad que las facultades anímicas superiores, el juicio y la comparación, ya habían empezado a funcionar; y, por otra parte, ya había empezado a distinguir entre representaciones estrechamente relacionadas. Esta comparación es especialmente necesaria en el caso de los sonidos articulados. Sabemos, en efecto, que las palabras de un idioma extranjero inicialmente siempre nos parecen únicas e indiferenciables.

$0 ; 8(5)$ [27] Las asociaciones de ideas fueron aumentando cada vez más y, a partir de ellas, se formaron ya sensaciones y apetitos compuestos. El 28 de Abril, colocamos, por broma, a otro niño en el pecho de la madre; nuestro muchacho se mostró inquieto e intentó apartarlo, a pesar de que hacía muy poco que él había mamado. Así, pues, el niño no sólo había establecido una conexión entre las impresiones visuales externas del acto de mamar y las sensaciones del gusto y del placer que de él se deriva, de tal manera que era capaz de reconocer lo que el otro niño estaba haciendo por la posición en que se encontraba, sino que además a todo esto se unía una sensación desagradable de que se le estaba quitando algo, que propiamente le correspondía a él mamar de ese pecho. De aquí, ese esfuerzo por apartar [al otro niño] y esa especie de envidia. El hambre no podía ser la razón de este hecho, puesto que el niño acababa justamente de saciarse.

0;8(20) [28] El día 13 de Mayo, aparecen síntomas evidentes de reflexión y de un incremento en la capacidad de discriminación. Siempre que aparecía ante él algo nuevo o extraño, el niño lo señalaba con el dedo, con el fin de hacer que los demás también se fijasen en ello, y emitía al mismo tiempo el sonido «iha!, ¡ha!. ${ }^{12}$ Que tanto la indicación como la exclamación estaban dirigidas a otras personas queda demostrado por el hecho de que el muchacho se quedaba satisfecho tan pronto como los demás daban muestras de que estaban atendiendo al mismo objeto que el niño. Aquí puede verse cuán profundamente subyace en la naturaleza humana el deseo de comunicarse con los demás y percibir su participación en nuestro interés por algo. Al principio, la reflexión es excitada de forma mecánica por las impresiones continuas, fundamentalmente las placenteras, a unirse a la comprensión de los sentimientos de los demás [Nachempfindung]; después se mezcla de forma imperceptible con la sensación [Empfindung]. ${ }^{13}$ Pero basta con que 
ciertas representaciones se hayan hecho familiares y se hayan llevado a cabo asociaciones entre ellas para que lo nuevo y lo extraño se perciban con mayor rapidez, y el acto de darse cuenta se produce incluso sin la presencia de sensaciones continuas y agradables; a eso se debe el que en niños muy pequeños no percibamos ningún indicio de reflexión. A esto se añade el que, como consecuencia de la ampliación del número de representaciones, crece el afán de hacerse con más, con lo cual el alma está esperando siempre nuevas impresiones. El niño también demostraba que poseía estas representaciones ya plenamente acabadas y totalmente familiares por el hecho de que era capaz de reconocer siempre a su madre, y a un par de personas más, con toda precisión, incluso a cierta distancia, basándose exclusivamente en su aspecto externo.

[29] Hasta el 9 de Septiembre no se observó nada nuevo, ${ }^{14}$ pero ese día aparecieron síntomas claros de representaciones más desarrolladas. Cuando veía un vaso de agua, extendía la mano hacia él y, cuando estaba cansado, la extendía hacia su cuna. Así, pues, había aprendido a conocer cada vez mejor los objetos que servían para satisfacer sus necesidades físicas; igualmente, había aprendido a hacer uso de sus miembros para satisfacerlas. Los movimientos, que al principio eran puramente mecánicos y accidentales, habían ido dejando tras de sí representaciones; éstas se unieron a las sensaciones provocadas por las necesidades y, de esta manera, las manos, junto con el resto del cuerpo, empezaron a moverse con el fin de satisfacer los apetitos. Ya era capaz de imitar en voz alta algunos sonidos, pero, sin embargo, no era capaz de conectarlos con las ideas correctas. Era capaz de comprender perfectamente nombres aislados correspondientes a objetos familiares, de tal manera que, incluso en ausencia de los objetos en cuestión, el niño tenía presente su imagen y era capaz de girar la cabeza para buscarlos y señalarlos. ${ }^{15} 1 ; 0(22)$ No tardó tampoco mucho en aprender a comprender frases aisladas. El día 14 sabía ya lo que quería decir «haz una reverencia» o «caza la mosca», instrucciones que siempre seguía de forma apropiada.

[30] Aún no poseía ninguna representación en absoluto sobre la caída de los cuerpos desde lo alto ni de la diferencia entre el espacio vacío y el espacio lleno. El 14 de Octubre aún pretendía dejarse caer desde lo alto y, muchas veces, dejaba caer al suelo el bizcocho cuando intentaba mojarlo. El 9 de Noviembre se puso claramente de manifiesto el mayor grado de actividad y espontaneidad de las almas humanas: cuando por primera vez conseguía hacer algo por sí mismo, comunicar a sus juguetes un movimiento determinado o algo por el estilo, el niño daba muestras evidentes de contento y encontraba placer en repetirlo. Por regla general, los niños se ponen muy contentos siempre que son capaces de hacer por sí mismos algo que hasta ese momento tenían que dejar que otras personas hiciesen por ellos. Por eso tienen tantas ganas de tomar la comida con sus propias manos y les apetece tan poco dejarse manipular por otros a la hora de vestirse, bañarse y cosas por el estilo.

[31] La simpatía y el amor propio se habían desarrollado cada vez más hasta desembo- $1 ; 2(18)$ car en el sentimiento de honor. El día 10 de Noviembre lloraba si rehusábamos su mano, que solía tender como señal de su afecto. También daba muestras evidentes de disgusto si se le daba a entender que no había hecho algo bien. El amor propio hace su aparición muy pronto en los niños, incluso antes de que puedan observarse signos externos de él. Los besos y zalamerías de casi todos los que se acercan a ellos, especialmente los de la madre y las nodrizas, les enseñan muy pronto a valorarse a sí mismos, antes incluso de que la reflexión sobre sus propias acciones y la comparación con las que llevan a cabo los demás puedan proporcionarles un concepto más elevado de sí mismos. El 27 de Noviembre pronunció claramente unas palabras cuyo significado conocía bien. Fueron apapá y amamás, pero no las utilizó para llamar a las personas, sino casi puramente al azar, sin querer decir nada con ellas. Así, pues, parece que las palabras despertaban sus imágenes y representaciones correspondientes, pero no sucedía lo contrario, que las imágenes de los objetos y los deseos despertasen las representaciones de las palabras. Esto se debe, presumiblemente, al hecho de que los niños aprenden inicialmente las palabras más con el fin de comprender lo que quieren decir los demás que con el fin de expresarse ellos mismos, igual que los adultos, cuando aprenden un idioma extranje- 
ro, son capaces de traducir las palabras de éste a su lengua materna antes que de expresar significados con palabras de aquel idioma. Sólo algunos sonidos sencillos tenían significado en el niño, como, por ejemplo, aha, has, ${ }^{12}$ cuando algo nuevo le sorprendía, y algunos sonidos de indignación y de negación. Verdaderamente, el sonido shas parece el natural para la reflexión y la sorpresa. Se produce como consecuencia de la liberación repentina del aliento contenido, y el aliento se contiene porque el curso de las ideas se ve interrumpido por la irrupción inesperada de algo extraordinario y, repentinamente, es dirigido en una nueva dirección. ${ }^{16}$ Como los órganos del habla aún no estaban suficientemente ejercitados para producir todo tipo de sonidos articulados, especialmente

1;3(6) mismos significados. El 29 de Noviembre se observó una expresión de este tipo que evidenciaba una nueva combinación de representaciones y que dejaba traslucir un vestigio de facultad poética [Dichtkraft] espontánea. Se le había enseñado a contestar a la pregunta: « ¿ómo eres de grande? elevando sus manos hacia arriba. Ese día, intentábamos que dijese la palabra Grossmama [que en alemán significa «abuela» y está compuesta de «gross» le resultaba demasiado grande, y «mamá»], y, como la palabra «gross» le resultaba demasiado difícil de pronunciar, lo que hizo fue elevar las manos hacia arriba y decir, a continuación, «mamáx. Como ahora también conocía mejor los objetos externos y su relación con la satisfacción de sus necesidades y con su entretenimiento, sus deseos por determinados objetos se hicieron más intensos, y la menor resistencia, aunque fuera opuesta por cosas inanimadas, le provocaba una intensa cólera. Estos deseos eran persistentes y no los abandonaba hasta que alcanzaba su objetivo.

1;3(15) [32] El día 8 de Diciembre, el sentido de la vista ya se había desarrollado casi por completo y estaba ya muy ejercitado en la perspectiva. Le gustaba ver imágenes y sabía distinguir algunos objetos conocidos cuando los veía representados en grabados, a pesar de la pequeñez de su tamaño. El ciego de Cheselden nos ha enseñado cuánto ejercicio y cuánta comparación efectuados calladamente son necesarios para llegar a esto. La sim-

1;4(3) patía y el amor propio se desarrollaban cada vez más. El 26 de Diciembre daba muestras evidentes de alegría cuando se reían sus juegos o se le alababa. Ciertamente, con el fin de provocar la risa recurría a hacer todo tipo de movimientos y adoptar todo tipo de posturas, puesto que ahora ya era capaz de caminar completamente solo. También ahora se puso claramente de manifiesto el afán de imitación, al tener ya bajo su control en medida bastante considerable su cuerpo y los órganos del habla. Era capaz, por lo tanto, de reproducir todo tipo de sonidos; por ejemplo, la campana cuando sonaba. También aprendió a pronunciar varias palabras con significado, sobre todo, acoge, coge» [nehm, $n e b m$ ], cuando quería que le cogieran en brazos o que le subieran a su silla. Se observaron signos claros de la existencia de la capacidad de recordar, pero sólo mediante sensaciones actuales, nunca exclusivamente mediante representaciones. Cuando había estado muchas veces en un sitio determinado y reconocía ese sitio desde lejos, solía señalar con el dedo en esa dirección. Como aún carecía de lenguaje, las representaciones no podían aún discurrir libremente, con independencia de las sensaciones, de manera que el pasado tampoco podía aparecer en el recuerdo sin ayuda sensorial. El recuerdo se basa siempre en la comparación y en él siempre hay oculto un juicio imperfecto. Así, pues, aquí se encuentra ya un primer vestigio de la potencia del pensamiento exteriorizándose de forma autónoma. Esto es probablemente algo distinto de lo que manifiestan algunos animales, en cuyo recuerdo parece producirse un mero despertar de antiguas huellas y movimientos asociados, sin ningún tipo de juicios ni comparación propiamente dichos. Algunas experiencias, suponiendo que sean fiables y exactas, parecen sugerir que sólo en el elefante podría darse algo más. La capacidad de juzgar se puso de manifiesto aún

1;4(19) con mayor claridad el 11 de Enero de 1783, al ser capaz el niño de reconocer su propia imagen en el espejo, en el que le gustaba mirarse y ante el cual ensayaba todo tipo de posturas. Desde muy pequeños, los niños suelen ser colocados a menudo ante el espejo y, por lo tanto, aprenden a base de numerosas experiencias que en el espejo todo es pura imagen, y, mediante la comparación de la imagen con sí mismos, terminan por aprender que se trata de su propia imagen. Para llegar a esto, son necesarias ciertamente muchas y muy frecuentes comparaciones, pero éstas no pueden tener ningún efecto en ausen- 
cia de la capacidad del juicio. Un rasgo especial del amor propio puede observarse en el hecho de que, por encima de todas las demás imágenes, uno prefiera siempre la suya propia; nos divertimos en la contemplación de la propia imagen gracias a la reflexión. Por este motivo, este fenómeno no se da en los animales. Un perro, al verse por primera vez reflejado en un espejo, se pone a ladrar porque confunde su imagen con otro perro. Cuando, después de numerosos intentos, la imagen no responde, el perro se calla, sin que sepamos si se ha dado cuenta del engaño o se ha cansado de ladrar sin obtener réplica. Pero nunca encontraremos que experimente una sensación placentera en la contemplación de su propia imagen, esto se debe con toda certeza a que la capacidad de reflexión del perro no va tan lejos como para ser capaz de regocijarse en sí mismo y decirse: ese soy yo, esos son mis rasgos. ${ }^{17} \mathrm{El}$ ansia de imitación aparecía ahora en el niño de forma cada vez más extensa. Además de imitar numerosos sonidos, se esforzaba también por remedar conversaciones, produciendo, con ese fin, secuencias de sonidos incomprensibles. La imitación empieza siempre por los aspectos más superficiales de las cosas, ya que éstos son los que más llaman la atención de los sentidos. Asimismo, no cabía duda de que poseía algunas representaciones sobre el sentido del habla, ya que acompañaba los sonidos carentes de significado con gestos mediante los cuales se aclaraba su sentido. Si, por ejemplo, quería ser colocado en un lugar determinado al que no era capaz de llegar por sí mismo y se le preguntaba a dónde quería ir, el muchacho señalaba con el dedo el lugar en cuestión y acompañaba esta acción con una serie de sonidos semiarticulados.

[33] Estaba muy interesado en procurarse representaciones nuevas y, en la medida de $1 ; 4(26)$ lo posible, precisas. El 18 de Enero se observó que, siempre que se ponía en sus manos un objeto nuevo, lo examinaba por todos sus lados, lo palpaba y le daba vueltas. Si sonaba algo en su interior, intentaba abrirlo para ver lo que había dentro, ya que había comprobado en numerosas ocasiones que objetos similares podían abrirse. También era ya capaz de comprender distintos tipos de frases; por ejemplo, «trae eso», «deja eso», «coloca eso allíw, acoloca eso ahí y cosas por el estilo. Pero seguía sin utilizar frases para obtener algo de los demás; en parte, porque los órganos del habla no se habían flexibilizado aún lo suficiente ni estaban aún bajo su control, y, en parte, también porque, aunque ciertamente el paso de las palabras a las cosas estaba firmemente establecido por el hábito, no ocurría lo mismo con su recíproco: el paso de las cosas a las palabras. El ansia de alabanzas y de aplauso se fue ampliando y reforzando cada vez más. Si había conseguido adoptar con su cuerpo una postura nueva y rara o si había conseguido producir algún movimiento inusual y sorprendente con sus juguetes, el niño se reía alegremente y miraba a su alrededor con la intención de obtener el aplauso de los demás. También le producía un placer especial el verse disfrazado o vestido con prendas nuevas, presumiblemente porque sabía que los demás solían alabarle y mostrarse agradablemente sorprendidos en tales ocasiones. Por esta época, le nació una hermana y empezaron a manifestarse síntomas de envidia. Quería pegarle siempre que la veía en el regazo de su madre o en la cuna, porque le resultaba desagradable ver cómo se le arrebataba algo que durante tanto tiempo había sido exclusivamente suyo. Hasta entonces, la simpatía se había manifestado en él casi exclusivamente en el hecho de que intentaba compartir con los demás sus propias sensaciones. Ahora también compartía las sensaciones de los demás y se ponía a llorar cuando su hermana lloraba. Asimismo, se observó un rasgo que daba fe de la existencia de una capacidad de juicio más desarrollada y una capacidad reflexiva más avanzada. Se le había prohibido en numerosas ocasiones tocar ninguna cosa comestible que no le hubiera sido expresamente dada, sin conseguir, sin embargo, quitarle esa costumbre. Ese día, había conseguido hacerse con un terrón de azúcar sin ser visto, después de lo cual se deslizó furtivamente a un rincón en el que no podía ser visto. No sabíamos a qué obedecía su conducta y cuando intentamos averiguarlo, le encontramos comiendo el terrón de azúcar. Los animales, cuando han sido castigados de forma repetida, salen corriendo con su botín a causa de una simple asociación de ideas, para evitar el castigo. No es esto lo que sucede en este caso, ya que el niño nunca había sido tratado de esa manera; se trataba de una genuina reflexión de que podría 
consumir el azúcar si no era visto, pero que, tan pronto como le vieran, se lo quitarían.

1;5(15) [34] El día 7 de febrero se puso de manifiesto la impresión tan agradable que, por su propia naturaleza, provoca la luz, cuando el muchacho se puso a observar la luna con especial satisfacción después de que se le señalase. A partir de entonces, siempre que le pedíamos que nos mostrase la luna, la señalaba con especial alegría. Exactamente la misma sensación agradable le producían los rayos del sol al incidir en la habitación.

1;6(15) En el lenguaje se efectuaron notables progresos. El día 8 de Marzo, al ver los objetos, repetía los nombres que tantas veces había tenido ocasión de escuchar. Sin embargo, aún le resultaba difícil pronunciar las palabras de varias sílabas. Habitualmente, sólo solía pronunciar las últimas sílabas de éstas o la sílaba sobre la que recaía el acento principal, puesto que son éstas las que más llaman la atención del oído. No era capaz de pronunciar bien las consonantes $z$, sch, $w$, st y $s p$, ni los diptongos. Las consonantes más fáciles de pronunciar para él eran $p, t$ y $k$. Las primeras, por su composición, requieren, por una parte, una mayor flexibilidad de los instrumentos del habla y, por otra, un oído más fino, ya ejercitado, para captar correctamente el sonido. Exactamente lo mismo sucede en el caso de los sonidos dobles. ${ }^{18}$ Su cada vez más desarrollada espontaneidad también se ponía de manifiesto con mayor claridad en el hecho de que le gustaba acometer empresas cargadas de dificultades, como arrastrarse por rincones estrechos, adoptar posturas arriesgadas, transportar objetos pesados, y cosas por el estilo. Las cosas habituales y demasiado fáciles no le proporcionaban ocupación suficiente, no le resultaban lo bastante distraídas. A esto hay que añadir que el hecho de vencer una dificultad nos proporciona un sentimiento de mayor y más amplia potencia. Ambas características se encuentran profundamente arraigadas en la naturaleza humana, y no en virtud de la educación o por sentimientos imbuidos por el acicate de la ambición; si no, no se manifestarían en el niño tan pronto y mediante una causa puramente interna; o, lo que todavía es más importante, los padres y otros adultos podrían suprimirlas con rapidez y facilidad cuando se esfuerzan, como debe de ser, por reprimir la osadía excesivamente grande de los niños por temor a sus consecuencias, recurriendo incluso con frecuencia al castigo.

1;7(4) [35] El 27 de Marzo, ya era capaz de pronunciar palabras de dos sílabas, conocía casi todas las partes externas de su cuerpo y era capaz de mostrarlas correctamente cuando se le decían los nombres. También era capaz de reconocer por su nombre casi todo lo que había situado en las habitaciones. También entonces el lenguaje empezó a ser utilizado de acuerdo con su determinación; las palabras eran asociadas inmediatamente a las ideas, de tal manera que la idea de una cosa llevaba aparejada consigo al mismo tiempo su nombre. Si al muchacho le apetecía obtener algo, solía denominarlo primero con su nombre, aunque esto sólo lo hacía aún con unas pocas cosas. Sin embargo, aún no le era posible unir varias palabras en una oración. Pero también a este respecto se ejercita-

$1 ; 9$ (10) ba en silencio, pues el día 3 de Junio ya consiguió pronunciar frases breves, compuestas por un verbo y un sustantivo, pero sin corrección gramatical. En lugar del imperativo, utilizaba siempre el infinitivo, y el nominativo era utilizado en lugar de cualquier otro caso que se necesitase; el artículo era ignorado por completo. El nominativo era el caso que él había oído principalmente cuando se le nombraban cosas. Todavía no existía ninguna noción del sentido de las otras desinencias casuales; a esto hay que añadir que éstas suelen ser suprimidas en la pronunciación. El infinitivo es el tiempo verbal que más utilizamos, ya que los demás tiempos los expresamos la mayoría de las veces mediante éste, cambiando la posición de otras palabras, de manera que era el infinitivo el que se había grabado fundamentalmente en su memoria. Probablemente, esta incorrección gramatical tiene su fundamento en la peculiar organización de nuestro idioma. Es extraordinariamente difícil desacostumbrar a los niños de la suciedad, especialmente enseñarles a que no se ensucien ellos mismos. Aunque el muchacho no podía soportar la suciedad ni en sus dedos ni en su camisa, hasta el punto de que no quería volver a ponerse una camisa ensuciada, de momento no había sido posible hacer que se mantuviese totalmente limpio. Después de ocurrida la cosa, sabía nombrarla muy bien y sabía también pedir que se le limpiase; asimismo, se mostraba avergonzado de lo acontecido. La razón de que esto suceda es que los niños no sienten con la suficiente claridad las 
necesidades de evacuación y, ensimismados en sus juegos, no se dan cuenta de ello. La envidia y el pundonor se iban desarrollando cada vez más. Si hacíamos mimos a su hermana, entonces se acercaba para recibir mimos él también. Si ella tenía algo en su poder, él intentaba arrebatárselo y llegaba incluso a intentar pegarla a escondidas.

[36] La capacidad de recordar se encontraba ya muy ejercitada. El día 20 de Julio llegó a un lugar de la casa en el que hacía 4 semanas que había sido castigado por haberlo ensuciado. Inmediatamente, y sin mediar ningún otro motivo, dijo que quien ensuciaba el cuarto recibía azotes. Por supuesto, no lo dijo con palabras perfectas pero sí con la suficiente claridad como para dar a entender lo que quería decir. Así, pues, se habían conservado representaciones de aquella otra ocasión. Sin embargo, si le preguntábamos por algo que había ocurrido unas horas antes, ya no se acordaba, presumiblemente porque el recuerdo sólo tenía lugar aún mediante sensaciones presentes y no mediante el curso interno de las representaciones. Lo que acabamos de decir muestra cuánto cuesta llegar a tener bajo control voluntario los propios pensamientos de tal manera que puedan evocarse a voluntad representaciones ausentes.

[37] También a este respecto no tardaron mucho en producirse importantes avances, de manera que las cadenas de representaciones asociadas se fueron haciendo cada vez más amplias, y su recorrido hacia atrás o hacia adelante se fue facilitando paulatinamente. El 24 de Julio oyó cómo graznaban unos patos sin verlos, e inmediatamente dijo «pa- $1 ; 11(1)$ tos», a pesar de que sólo en raras ocasiones los había visto y oído. Así, pues, aquí puede verse cómo el graznido de los patos se encuentra asociado a la imagen del ave, y la imagen a la palabra. Este ejemplo, además de asociación, supone también reflexión, que es la que pone de relieve que ambas impresiones, la auditiva y la visual, provienen de un mismo objeto y, por consiguiente, deben de ser representadas en correspondencia la una con la otra. Las ideas que se han asociado con anterioridad se van conexionando entre sí cada vez con más fuerza, de tal manera que, incluso al cabo de varios meses, ya no se separan. El 26 del mismo mes, al ver unas patatas, alimento que ya con anterio- $1 ; 11(3)$ ridad había comido con gusto pero que hacía varios meses que no veía, inmediatamente dijo spatatas» ["Kartoffeln»]. Gracias a esto y a la mayor cantidad de palabras que había aprendido, las cadenas de representaciones se hicieron más independientes de las impresiones externas, y se puso de manifiesto que en su pequeño cerebro ya se habían desarrollado varias representaciones de forma espontánea y se habían integrado en cadenas. El niño había oído contar cómo una tormenta había matado a una muchacha. Los gestos del narrador le habían causado una profunda impresión, de tal manera que, cuando más adelante se presentó una ocasión propicia, intentó volver a contarlo utilizando palabras entrecortadas y gestos; ciertamente su relato sólo pudo ser entendido por quienes habían estado presentes en la primera narración. ${ }^{19}$

[38] El 30 de Julio, por fin, es capaz de emitir por vez primera frases perfectas, aunque sólo de poca longitud; por ejemplo, «allí está él» [da stebt er], «allí yace él» [da liegt er.]. Paulatinamente, fue tomando cariño a su hermana y a un perro, que con anterioridad le habían sido objetos indiferentes. El 23 de Agosto, no quería que a ninguno de los dos se les causara dolor, ya que ambos empezaron a servirle de entretenimiento en el juego. También por estas fechas aprendió, en aras de la limpieza, a pedir cuando le urgía hacer sus necesidades. A propósito de esto, se le ocurrió un truco para conseguir otros objetivos mediante ello. Su silla era alta; desde ella podía dominar visualmente la mesa con toda comodidad y casi siempre podía alcanzar lo que había encima de ella. Ese día se dio cuenta de que encima de la mesa podía haber cosas de comer, y lo que hizo fue servirse del pretexto de sus necesidades evacuatorias para llegar a la mesa, puesto que sabía que en ningún otro caso sería satisfecho su deseo de ser puesto en la silla. En este hecho intervienen ya la deliberación, el juicio e incluso algún vestigio de razonamiento [Raisonnement], dado que sin éstos no sería posible aplicar ciertos medios para alcanzar un fin determinado, a menos que el muchacho hubiera sido inducido por la imitación. Pero la imitación puede descartarse en este caso por completo, así como la educación; todo es pura intuición ${ }^{20}$ propia. De algunos animales se cuentan ejemplos parecidos, pero como son tan raros y son referidos por autores que los cuentan de oídas, 
tenemos razones para no considerarlos demasiado fiables. El muchacho, cuando su hermana no hacía lo que él quería, solía referirse a ella con el apodo de stontas. Así, pues, su amor propio le había llevado hasta la comparación de los demás consigo mismo.

$2 ; 0$ (3) [39] El 26 de Agosto ya se había desarrollado una oscura idea de propiedad. El niño no quería que su hermana se sentase en su silla o que le pusieran su ropa; decía que eran sus cosas. Los orígenes del deseo de poseer algo de forma exclusiva y no dejar que lo utilicen los demás radica, sin duda, en el miedo de verse privado de su uso en ese momento, miedo que surge de la situación misma. Por eso puede encontrarse este deseo en niños muy pequeños e incluso en algunos animales; sin embargo, es algo que desaparece tan pronto como están saciados. Aquel otro deseo, la verdadera causa de la propiedad estable, que sigue existiendo aún después de usado algo, tiene como origen el miedo a perder el disfrute o uso futuro de alguna cosa, lo que, por lo tanto, supone ya la existencia de previsión, algo de lo que los animales son incapaces. Aunque haya muchos animales que hacen acopio de provisiones para el invierno, no podemos considerar esto como previsión, ya que esos animales actúan así antes incluso de que hayan tenido ocasión de aprender por experiencia lo que es el invierno y las necesidades que acarrea. Pero si el niño no deja que se le coja ninguna de sus cosas, a él, en cambio, le gusta coger las de su hermana. El deseo de tener más no le dejaba darse cuenta de que lo que él deseaba en relación a sus cosas podía igualmente ser deseado por su hermana en relación a las suyas. Cuando experimentamos un deseo vivo, pensamos exclusivamente en nosotros mismos, desapareciendo cualquier otra consideración.

Presumiblemente, éste es el motivo por el que los pueblos no cultivados despojan tan - fácilmente a los extranjeros de sus pertenencias, mientras que entre ellos respetan la propiedad; en efecto, consideran a los extranjeros como seres respecto a los cuales la observación de este deber no es necesaria, y que no tienen nada que ver con ellos. Además, han aprendido a dominar sus apetitos sólo en muy escasa medida.

$2 ; 2(6) \quad[40]$ Con la creciente ejercitación en el uso del lenguaje y el aprendizaje de numerosas palabras, las ideas fueron cayendo cada vez más bajo la voluntad y el arbitrio del alma, de tal manera que podían evocarse por impulso propio secuencias más numerosas y más largas, y también podían producirse secuencias de pensamientos. En virtud de esto, ganaron en ejercicio aquellas facultades que con las ideas encuentran más ocupación y elaboración, especialmente la facultad poética [Dichtkraft]. El día 29 de Octubre, el niño colocó ante él unos cuantos tronchos de repollo e hizo que representasen a diferentes personas saludándose entre sí. Sin ninguna motivación exterior, habían sido evocadas las representaciones de unas personas saludándose entre sí, y estas imágenes habían sido trasladadas a los tronchos de repollo, de manera que éstas representaban a aquéllas. Así, pues, la primera manifestación de la facultad poética parece consistir en el hecho de trasladar imágenes conocidas a objetos diferentes. Asimismo, en ese comportamiento existe una asociación de ideas arbitraria y de elaboración propia, que es el fundamento original de todo lenguaje, de todo arte de hacerse entender mediante signos. Hasta ahora, nunca se ha observado en un animal nada parecido, nunca se ha observado entre las imágenes y representaciones que poseen los animales una asociación introducida de forma espontánea. Así, pues, la razón por la que los animales no aprenden un lenguaje radica ciertamente en algo más profundo que en la falta de la flexibilidad adecuada en los órganos del habla. ${ }^{21}$

$2 ; 2(21)$ [41] También empezó a manifestarse entonces la facultad del pensamiento y la búsqueda de explicaciones satisfactorias. En la mañana del 13 de Noviembre, el niño se asomó a la ventana y descubrió en el cielo una nube brillante: en ese instante se le vino a la mente un arco iris que había visto varias semanas antes e inmediatamente se construyó el juicio: veo un arco iris. Con toda probabilidad, la relación de semejanza es el primer paso hacia el juicio, ya que la semejanza evoca imágenes ausentes y, de esa manera, provoca la comparación entre lo que se percibe en ese momento y lo que se ha conocido anteriormente. Pero, cuando le dijimos que eso no era un arco iris, replicó de inmediato: el arco iris está ahora durmiendo [der Regenbogen schläft jetz]. Con toda probabilidad, lo que pretendía era simplemente darse una razón por la que eso no podía ser 
en ese momento un arco iris. Así, pues, la facultad del pensamiento ya ha alcanzado el punto en que es capaz de encontrar razones para el juicio. Asimismo, hay una demostración más clara de esa tendencia al antropomorfismo que se encuentra tan profundamente arraigada en la naturaleza humana, y en virtud de la cual se representa el mundo exterior de forma humanizada y se piensa en lo inanimado como animado. Lo primero se basa, sin duda alguna, en el hecho de que uno siempre se imagina lo desconocido mediante lo conocido, lo que resulta necesario para intelectos de naturaleza limitada, si no quieren verse parados y ver inhibida su actividad de forma incómoda a cada instante. A esto hay que añadir que, sin que nosotros nos demos cuenta, gracias a la actividad y la asociación espontánea, con las sensaciones e imágenes nuevas se mezclan ideas habituales y familiares, actuando de tal manera que lo desconocido siempre es representado mediante una imagen que nos es ya conocida. Ahora bien, no hay nada que nos resulte más próximo ni más familiar que nosotros mismos. Con lo cual, las imágenes de nuestros estados emocionales, de nuestra forma de actuar, se mezclan con las representaciones de los objetos externos a nosotros, y, por eso, pensamos que todo es semejante a nosotros, animado como nosotros lo somos, y actuando por los mismos motivos y las mismas facultades. Esto último se debe también a una razón más específica: lo inanimado nos ofrece muy poca distracción y, por lo tanto, para procurarnos más ocupación con ello, hemos de aproximarlo a nosotros haciéndolo animado. De ahí que a los niños les guste tanto transformar sus juguetes inanimados en seres humanos, como se hizo patente en el ejemplo anterior con los tronchos de repollo.

[42] Ese mismo día, observamos un ejemplo semejante a éste. Le puse mi reloj de bolsillo en el oído y, después de escuchar el sonido durante un rato, dijo que el Fripón (un cachorro de perro que teníamos en casa) estaba encerrado dentro. Así, pues, supuso que el movimiento y el sonido continuo provenían de un ser animado, lo cual es un pensamiento asumido por casi todos los pueblos primitivos y que tiene su origen precisamente en el antropomorfismo, según el cual todo lo que se mueve es concebido como semejante a nosotros o a los animales y, por eso, es representado como algo animado. Hay algo que queda claro a partir de estos ejemplos: que el origen de esa tendencia en los pueblos primitivos radica en las ideas de un entendimiento aún sin cultivar y que no ha sido guiado mediante las experiencias adecuadas. Esto queda confirmado por otro juicio emitido por el niño el día 2 de Abril. Cuando al anochecer dejó de verse el sol 2;7(10) en el cielo, dijo: ase ha ido a la cama. Por la mañana se vuelve a levantar, bebe té y come pan con mantequillaw. Todos estos juicios nacían exclusivamente a partir de reflexiones propias; nadie le había dicho nada parecido anteriormente, de manera que no podía estar ateniéndose a ideas ajenas. Asimismo, la diversidad de las ocasiones muestra que en la base de esto no hay nada aprendido o, simplemente, imitado, sino que se trata de algo que claramente ha pensado él mismo.

[43] La autoestima empezó a desarrollarse más y a convertirse en autoestima propiamente dicha, de manera que ahora le preocupaba el que otras personas, sin distinción, le alabasen o le censurasen. El 14 de Febrero de 1784, creyendo que había hecho algo 2;5(22) bueno, afirmó que la gente diría: «Qué chico tan majo!»; si, cuando estaba haciendo una travesura, le decíamos que el vecino le estaba viendo, entonces dejaba de hacerla de inmediato.

[44] Hasta aquí llegan mis observaciones; otros asuntos que han surgido mientras tanto me impiden prolongarlas durante más tiempo. Me gustaría mucho que otros pudieran efectuar observaciones parecidas; entonces, mediante la comparación podrán determinarse más cosas, y esa parte tan importante de la psicología que investiga el desarrollo de las facultades del alma humana, que hasta ahora se ha desarróllado tan poco pero que es el fundamento de toda pedagogía, podrá hacer progresos considerables. 
* A la izquierda de cada párrafo, entre corchetes, aparece el número que le corresponde. También aparece la edad del niño en el momento de la observación, según la práctica habitual de hacer constar, primero, los años, después los meses y, finalmente, entre paréntesis, los días.

1 En 1728 el cirujano inglés William Cheselden (1688-1752) publicó unas notas sobre un muchacho de 13 años al que había operado de cataratas y había recobrado la vista. Cheselden recoge en su informe las reacciones del chico al recobrar la vista. Señala que el paciente no era capaz de diferenciar los colores, de reconocer las formas de los objetos que le eran familiares mediante el. tacto, ni de distinguir las distancias. Hasta dos meses después de la operación tampoco fue capaz de reconocer lo que representaban los dibujos que se le mostraban, como recuerda Tiedemann en [32]. El informe de Cheselden, que contenía datos importantes para la disputa sobre el origen sensorial o innato de los conocimientos, se difundió ampliamente en el siglo XVIII.

2 Desde épocas lejanas se han recogido en la literatura casos de niños criados por animales, con escaso o nulo contacto con otros seres humanos, como es el caso de Rómulo y Remo. En un período más reciente se empieza a señalar el hallazgo de niños criados en los bosques entre animales. En 1344 se descubrió un niño lobo en Hesse (descrito por Camerarius en 1602) y otro en Wetteravia. Hasta la época en la que escribía Tiedemann se había señalado al menos la existencia de 15 casos. Este tipo de descubrimientos se popularizaron y fueron ampliamente difundidos cuando escribieron sobre ellos grandes figuras de la ciencia y la cultura del siglo XVIII. Rousseau hace referencia a cinco casos en su Discours sur l'origine de l'inégalité parmi les hommes (Discurso sobre el origen de la desigualdad entre los hombre) (1754), Condillac (1746) cita otro, La Condamine escribió un librito sobre uno de ellos. Pero posiblemente fue Linneo (1758), el gran clasificador del mundo natural, el que les dio entrada en la ciencia al hacer mención de siete casos en la $10^{2}$ edición de su Systema naturae, que amplía a diez en la 13 edición. Linneo los incluyó como una de las subdivisiones del género homo, el bomo ferus, cuyas características distintivas eran ser tetrapus, mutus, e hirsutus, es decir andar a cuatro patas, carecer de lenguaje y estar cubiertos de pelo.

El interés por estos casos se debía no sólo a lo curioso de ellos, sino a la luz que podían arrojar sobre el problema de lo innato y lo adquirido, o la influencia de la naturaleza y la cultura sobre el hombre. Tiedemann podía tener conocimiento de ellos a través de muy distintas fuentes, pues son muchos los autores que se ocuparon de ellos en esa época.

Pocos años después del rrabajo de Tiedemann se encontró a Victor de L' Aveyron, el famoso niño salvaje estudiado por Itard (1801 y 1807). Estos casos, que continúan apareciendo, han sido estudiados por Singh y Zingg (1942) y Malson (1964).

3 Tiedemann apunta aquí claramente el problema de las diferencias individuales, indicando que los datos de su sujeto sólo podrán generalizarse con la obtención de datos de otros niños. Pero también parece suponer que otros sujetos sólo podrían aportar datos sobre otras velocidades, pero no sobre otros desarrollos.

${ }^{4}$ En su déseo de apoyar la posición empirista Tiedemann sostiene que incluso mamar es algo que debe aprenderse. Pero al mismo tiempo admite lo que califica de reacción mecánica, que no sería otra cosa que un reflejo de succión. Piaget en su obra La naissance de l'intelligence chez l'enfant (El nacimiento de la inteligencia en el niño) (1936), el estudio moderno más importante sobre el desarrollo sensorio-motor, establece un primer estadio de desarrollo que denomina del cejercicio de los reflejoss, durante el que los reflejos innatos deben consolidarse, y cita cómo esos reflejos pueden debilitarse o extinguirse si no se practican.

El acto de succión es muy complejo y está formado por distintos tipos de respuestas que han sido estudiadas detenidamente utilizando ingeniosos aparatos. Ver por ejemplo Sameroff (1968).

s El enfajamiento es una costumbre que consiste en envolver a los niños de los pies al cuello en pañales y mantillas inmovilizándoles. Esta práctica debió de ser común èn numerosos lugares de Europa, y en la actualidad se sigue utilizando en algunas culturas (por ejemplo, los indios hopi). Fuertemente criticada por los pediatras, basándose en el argumento de que la inmovilización del niño podría acarrear retrasos en su desarrollo psicomotor, observaciones y experimentos recientes parecen haber demostrado, sin embargo, que no sólo no acarrea efectos negativos, sino que tiene su razón de ser como una poderosa técnica para controlar lo que actualmente se conoce con el nombre de restados del niño. En efecto, se ha demostrado que un enfajamiento perfecto (es decir, aquel en que el niño ve completamente inmovilizadas sus extremidades) induce rápidamente un estado de relajación, desapareciendo conductas como la de llorar. Un enfajamiento imperfecto, en cambio, produce efectos contrarios (vid. Wolff, 1987).

Tiedemann hace varias referencias a la práctica de enfajamiento con su hijo Friedrich. En una de ellas anticipa la opinión de que el enfajamiento podría producir un retraso en el desarrollo del niño; concretamente en el desarrollo de las ideas de distancia y de la diferencia entre el cuerpo propio y los objetos externos. Argumenta que, al tener los brazos sujetos, los niños se ven privados de la experiencia y el ejercicio a los que de otro modo tendría acceso, y que posiblemente los niños podrían adquirir antes las ideas anteriormente citadas si no fuera por ese impedimento. Hay que señalar, sin embargo, que Tiedemann no parece considerar ese retraso como algo especialmente negativo y ni mucho menos patológico; más bien parece que su interés reside, una vez más, en resaltar la importancia de la experiencia y el ejercicio como motores del desarrollo.

- G'Uná de las palabras que aparece con más frecuencia.en el texto es el término «Vorstellungs. 
literalmente rrepresentacións. Sin embargo, por el contexto en que se usa parece evidente que podría traducirse de varias otras maneras, especialmente por sideas e, incluso, aimagens. No es este el caso de otros autores alemanes, como, por ejemplo, Kant, que introduce una distinción conceptual entre «Vorstellung» e aldees. Nosotros hemos optado por traducir «Vorstellung» por arepresentación, a pesar de que en determinados pasajes el autor casi hacía explícita la homonimia y que tanto Michelant como Langer y Murchison, en sus respectivas versiones francesa e inglesa, recurren frecuentemente al término sideas.

7 Las respuestas de la planta del pie en el recién nacido son variadas. Se habla de un reflejo de prensión plantar que consiste en una flexión de los dedos del pie. Posiblemente a esto es a lo que se refiere Tiedemann. El reflejo de Babinski, por el contrario, consiste en una extensión del dedo gordo, acompañada a veces por una extensión de los restantes dedos que forman una especie de abanico.

${ }^{8}$ Steiner ha mostrado en una serie de estudios (ver, por ejemplo, 1979) que los recién nacidos, que nunca han ingerido ningún alimento, distinguen perfectamente entre sabores dulces, agrios y amargos, y lo manifiestan mediante expresiones faciales claramente diferenciables. Incluso los niños prematuros, nacidos en el séptimo mes de gestación, producen respuestas diferentes a diferentes gustos, y lo mismo pasa con niños sin encéfalo y con otras malformaciones del sistema nervioso central.

9 Esta misma denominación la recoge Sigismund al comienzo de su libro Kind und Welt (El niño y el mundo) publicado en 1856, señalando que es habitual en Turingia.

10 Tiedemann se plantea aquí el importante problema de si las respuestas y el interés por las personas se debe en su origen a una predisposición innata o a que las personas son fuente privilegiada de estímulos y productoras de modificaciones del ambiente.

11 Piaget (1936) recoge a partir de los 4(12) en adelante en su hijo Laurent ejemplos de anticipación a través de la interpretación de señales o índices (observaciones 108 y 109).

${ }^{12}$ Recuérdese que en alemán la ahs se pronuncia ligeramente aspirada.

${ }^{13}$ Esta afirmación de Tiedemann resulta extremadamente oscura. Las versiones inglesa y francesa ofrecen traducciones distintas que, sin embargo, no se ajustan a la estricta literalidad del texto, posiblemente porque intentan extraer sentido de un pasaje en el que resulta muy difícil saber qué es lo que el autor quería decir. La propuesta de Langer y Murchison es traducir *Nachempfindung*, no en su sentido normal (acapacidad de comprender los sentimientos de los demáss), sino en su sentido literal, como un compuesto de «nach» («post» o «posterion) y «empfindung» («sensación»). De manera que ellos utilizan el término inglés «after-sensations, es decir, «post-sensación o lo que queda de una sensación después de que ha dejado de experimentarse. La interpretación de este párrafo sería, por tanto, que la reflexión al principio es estimulada maquinalmente por el efecto de sensaciones duraderas y placenteras, pero sólo aparece unida a lo que queda de esas sensaciones después de que hayan dejado de experimentarse; después, sin embargo, la reflexión llega a producirse al mismo tiempo que el acto mismo de la sensación.

${ }_{14}$ Durante casi cuatro meses no hay observaciones, pero no puede decirse que no pase nada durante ese tiempo. Ese lapso viene a coincidir con el cuarto estadio del período sensorio-motor, durante el cual se establece la coordinación de esquemas secundarios.

15 No parece que sea preciso tener una imagen de un objeto para realizar esa conducta. El objeto está presente en el entorno porque si no el niño no lo vería girando la cabeza. No es equivalente pues a la búsqueda de un objeto oculto.

${ }^{16}$ Aquí parece apuntarse una idea que Darwin desarrolló en su libro La expresión de las emociones en los animales y en el bombre (1872), la de que algunos sonidos que sirven para expresar emociones se originan en reacciones fisiológicas naturales. En la pág. 119 de su libro (trad. cast. de T. Fernández), Darwin se refiere a las expresiones vocales que acompañan la emoción de sorpresa en los siguientes términos:

«Cuando alguien se asusta o se asombra de repente, hay una tendencia instantánea, también por causas comprensibles, a prepararse para un esfuerzo prolongado y a abrir mucho la boca para hacer una rápida inspiración. De inmediato, cuando se produce la expiración total, la boca se cierra sin apretarla y los labios se sacan algo hacia afuera, si se llega a hacer uso de la voz se producirá, según Helmholtz, el sonico vocal O.. (Darwin, 1872, p. 119).

Darwin refiere a continuación cómo, si la sorpresa va acompañada de dolor, la contracción general de la musculatura determina que el sonido emitido por la boca sea un $\star 2 h \gg 0$ «ach . Sin embargo, más adelante (op. cit., p. 297), advierte que cuando la sorpresa va acompañada de satisfacción los labios pierden la forma elongada en favor de una apertura lateral tendente a la sonrisa, lo que, aunque él no lo dice, produciría un sonido semejante al descrito por Tiedemann.

${ }_{17}$ El reconocimiento en el espejo siempre ha sido un ítem típico de las escalas infantiles de desarrollo (vid., por ejemplo, Gesell, 1934), pero las reacciones de los niños y los animales frente a su imagen especular sólo han sido objeto de intensa investigación en los últimos años. En Mounoud y Vinter (1981), puede encontrarse una útil colección de trabajos sobre este tema. Curiosamente, aunque los autores de la compilación hacen una breve revisión histórica en la introducción a este volumen, mencionando, entre otras, las observaciones de Darwin y Preyer, no hacen referencia a esta primera observación de Tiedemann, que puede considerarse como singularmente precisa tanto en el caso del niño como en el del perro. Resulta difícil saber si la descripción de la conducta del animal proviene de observaciones propias o de ese aconocimiento de dominio públicos al que 
ya nos hemos referido anteriormente (ver el estudio que precede a esta traducción), aunque la exactitud y el relativo detalle con que se refiere la conducta del perro parecen apuntar a la primera posibilidad.

18 Mills (1985), en una reciente revisión sobre la adquisición de la lengua alemana, afirma que no existen aún estudios lo suficientemente detallados sobre la adquisición de la fonología en este idioma, y remite a un trabajo tan antiguo como el de Stern y Stern (1928) para encontrar algunos datos extensos. Estos autores confirman la facilidad y precocidad de adquisición de los fonemas «pp y ets y la dificultad de las consonantes que cita Tiedemann, pero afirman que también las guturales les resultan difíciles a los niños, lo que estaría en contradicción con lo que Tiedemann dice sobre el sonido $\mathrm{ks}$.

19 Se trata de una manifestación de lo que Piaget denominó cimitación diferidas, semejante a las observaciones que éste recogió. Por ejemplo, su hija Jacqueline a $1 ; 4(3)$ ve a un niño manifestar una tremenda rabieta, y al día siguiente lo imita (Piaget, 1946, observación 52).

20 Hemos traducido aquí por «intuicións la palabra eEmpfindungs. En el resto del texto, esta palabra es traducida como asensacións, que es su significado habitual. Sin embargo, por el contexto en que aparce empleada en este párrafo, parece evidente que Tiedemann la está utilizando en otra acepción. Nos ha parecido que la más adecuada de las que aparecen en el diccionario era la de epresentimientos o sintuicións.

${ }^{21}$ La observación de lo que hoy en día llamaríamos un episodio de juego simbólico lleva a Tiedemann a hacer una serie de consideraciones sumamente agudas sobre la existencia de una capacidad general subyacente a la utilización arbitraria de símbolos, que recuerda muy directamente la noción de afunción semiótica, o simbólicas que Piaget desarrollaria siglo y medio después (Piaget, 1946). La consideración final sobre la ausencia de esta capacidad en los animales como razón «profundas por la que no son capaces de aprender el lenguaje recuerda una reciente polémica desatada por los experimentos sobre enseñanza de lenguajes no vocales a monos antropoides, en la que algunos autores defienden la tesis contraria a la de Tiedemann, es decir, que los simios poseen algunas de las capacidades subyacentes para el aprendizaje del lenguaje, pero que son razones periféricas (la distinta constitución del aparato fonador) las que explican su total incapacidad para aprender el lenguaje hablado (véase Sánchez de Zavala, 1976).

\section{Referencias de las notas}

DARWIN. C. (1872) The expression of the emotions in man and animals. Londres: J. Murray. Trad. cast. de Tomás Fernández Rodríguez: La expresión de las emociones en los animales y en el bombre. Madrid: Alianza, 1984.

GESELI. A. (1934) Infant behavior: its genesis and growth. Nueva York: Greenwood Press.

LiNNEO. C. von (1758) Systema naturae, 10.2 edición. Estocolmo: Laurentii Salvii. 13 Edición Leipzig: Geoge Immanuel Beer, 1788.

Malson, L. (1964) Les enfants sauvages. París: Unión Générale d'Editions. Trad. cast. de Rafael Sánchez Ferlosio: Los niños selváticos. Madrid: Alianza, 1973.

MiLs, A. (1985) The acquisition of Germans. En Slobin, D. I. (ed.) The cross-linguistic study of language acquisition. Vol. 1: the data. Hillsdale: L.E.A. pp. 141-254.

MoUNOUD, P. y VINTER, A. (eds.) (1981) La reconnaissance de son image chez l'enfant et l'animal. Neuchâtel: Delachaux et Niestlé.

PIAGET, J. (1936) La naissance de l'intelligence chez l'enfant. Neuchâtel y París: Delachaux et Niestlé. Trad. cast. de L. Fernández Cancela: El nacimiento de la inteligencia en el niño. Madrid: Aguilar, 1972. Nueva ed. Barcelona: Crítica.

Pinget. J. (1946) La formation du symbole chez l'enfant. Neuchâtel: Delachaux et Niestlé. Trad. cast. de José Gutiérrez: La formación del simbolo en el niño. México, F.C.E., 1961.

SAMEROFF. A.J. (1968) The components of sucking in the human newborn. Joumal of Experimental Child Psychology, 6, 607-623.

SÁNCHEZ dE ZAVALA, V. (1976) (comp.) Sobre el lenguaje de los antropoides. Madrid: Siglo XXI.

SIGISMUND, B. (1856) Kind und Welt. Vaterm, Muttem und Kinderfreunden gewidmet. Braunschweig: Vieweg. Nueva edición 1897. Trad. cast. de Rosario Fuentes: El niño y el mundo. Madrid: La Lectura, 1926.

SINGH, J.A.L. y ZiNGG, R.M. (1942) Wolf children and feral man. Nueva York: Harper.

STEINER, J.E. (1979) «Human facial expressions in response to taste and smell stimulation. Advances in Child Development and Behavior, 13, 257-295.

STERN, C. y STERN, W. (1928) Die Kindersprache. Leipzig: Barth.

WOLF, P.H. (1987) The development of behavioral states and the expression of emotions in early infancy. Chicago: The University of Chicago Press. 